\title{
Correction to: Effect of biosolid hydrochar on toxicity to earthworms and brine shrimp
}

\author{
Tatiane Medeiros Melo $\cdot$ Michael Bottlinger $\cdot$ Elke Schulz $\cdot$ Wilson Mozena Leandro • \\ Adelmo Menezes de Aguiar Filho $\cdot$ Yong Sik Ok · Jörg Rinklebe
}

Published online: 4 January 2018

(C) Springer Science+Business Media B.V., part of Springer Nature 2017

Correction to: Environ Geochem Health

(2017) 39:1351-1364

https://doi.org/10.1007/s10653-017-9995-5

Unfortunately, in the original publication of the article, Prof. Yong Sik Ok's affiliation was incorrectly published. The author's affiliation is as follows.

1. Kangwon National University, Chuncheon 24341, Republic of Korea

The original article can be found online at https://doi.org/10.1007/s10653-017-9995-5.

\section{T. M. Melo ( $\square)$}

Institute of Foundation Engineering, Water- and Waste-

Management, School of Architecture and Civil

Engineering, Soil and Groundwater Management,

University of Wuppertal, Pauluskichstraße 7,

42285 Wuppertal, Germany

e-mail: txmmelo@yahoo.com.br

\section{Bottlinger}

Department of Hydrothermal Carbonization, Trier University of Applied Sciences, Environmental Campus

Birkenfeld, 55761 Birkenfeld, Germany

e-mail: m.bottlinger@umwelt-campus.de

\section{E. Schulz}

Department of Soil Ecology, Helmholtz Centre for Environmental Research (UFZ), 06120 Halle, Germany e-mail: elke.schulz@ufz.de
2. O-Jeong Eco-Resilience Institute (OJERI), Division of Environmental Science and Ecological Engineering, Korea University, Seoul, Republic of Korea

\section{W. M. Leandro}

Department of Agronomy, Federal University of Goiás (UFG), 74690-900 Goiânia, Brazil

e-mail: wilsonufg@gmail.com

A. M. de Aguiar Filho

Department of Chemical Engineering, Federal University of Bahia (UFBA), 40210-630 Salvador, Brazil e-mail: adelmo.aguiar.filho@gmail.com

Y. S. Ok

Korea Biochar Research Center, School of Natural Resources and Environmental Science, Kangwon National University, Chuncheon 24341, South Korea e-mail: soilok@kangwon.ac.kr 
Y. S. Ok

O-Jeong Eco-Resilience Institute (OJERI), Division of Environmental Science and Ecological Engineering,

Korea University, Seoul, Republic of Korea

e-mail: yongsikok@korea.ac.kr

J. Rinklebe

Soil and Groundwater Management, University of

Wuppertal, Pauluskichstraße 7, 42285 Wuppertal,

Germany

e-mail: rinklebe@uni-wuppertal.de

\section{J. Rinklebe}

Department of Environment and Energy, Sejong

University, 98 Gunja-Dong, Guangjin-Gu, Seoul, South

Korea

\section{Springer}

